\title{
Successful treatment of extramedullary relapsed/refractory B-acute lymphoblastic leukemia with Inotuzumab ozogamicin before and after allogeneic stem cell transplantation
}

Anna G. Smirnova, Sergey N. Bondarenko, Ivan S. Moiseev, Inna V. Markova, Elena I. Darskaya, Irina K. Golubovskaya, Bella I. Ayubova, Elena V. Babenko, Ildar M. Barkhatov, Alexander L. Alyanskiy, Tatiana L. Gindina, Alexander D. Kulagin, Boris V. Afanasyev

Raisa Gorbacheva Memorial Research Institute of Pediatric Oncology, Hematology and Transplantation, Chair of Hematology, Transfusiology and Transplantology, Pavlov First Saint Petersburg State Medical University, St. Petersburg, Russia

Dr. Anna G. Smirnova, Raisa Gorbacheva Memorial

Research Institute of Pediatric Oncology, Hematology and

Transplantation, Pavlov First Saint Petersburg State Medical

University, L.Tolstoy St 6-8, 197022, St. Petersburg, Russia
Phone: +7 (812) 3386236

E-mail: dr.annasmirnova@gmail.com

Citation: Smirnova AG, Bondarenko SN, Moiseev IS et al. Successful treatment of extramedullary relapsed/refractory B-acute lymphoblastic leukemia with Inotuzumab ozogamicin before and after allogeneic stem cell transplantation. Cell Ther Transplant 2019; 8(2): 63-67.

\section{Summary}

Recent advances in treatment of relapsed/refractory B-Acute Lymphoblastic Leukemia (R/R B-ALL) are associated with targeted immune therapies, such as Blinatumomab, Inotuzumab ozogamicin and CAR-T cells. Several clinical studies demonstrate superior complete remission (CR) and allogeneic stem cell transplantation (allo-HSCT) rates after Blinatumomab or Inotuzumab treatment compared to conventional chemotherapy with different toxicity profiles. However, treatment of extramedullar lesions was not addressed in these trials.

\section{Case presentation}

We report two R/R B-ALL patients with extramedullar involvement. Case 1. A woman, 31 years old with Philadelphia positive B-ALL, being in second relapse not responding to Blinotumomab. Clinical progression was observed, with involvement of bone marrow (BM), cervical, mandibular lymph nodes and breast lesions. Complete BM and extramedullary remission was achieved after Inotuzumab followed by allogeneic stem cell transplantation from a matched related donor was performed. Case 2. A 25 years-old young woman exhibited a BM relapse after unrelated stem cell transplantation. Remission was achieved after Blinotumomab treatment. Inotuzumab was administered for 6th extramedullary relapse. A complete metabolic response was achieved after 4 cycles of Inotuzumab as shown by PET scanning.

\section{Conclusion}

The present cases demonstrate an opportunity for Inotuzumab administration after Blinotumomab failure in case of extramedullary relapse before and after allo-HSCT.

\section{Keywords}

Allogeneic hematopoietic stem cell transplantation, B-Acute Lymphoblastic Leukemia, Blinotumomab, Inotuzumab ozogamicin, extramedullary relapse. 


\section{Introduction}

Allogeneic stem cell transplantation (allo-HSCT) is the established option for high risk acute lymphoblastic leukemia [1]. However, allo-HSCT in refractory/resistant acute lymphoblastic leukemia (R/R ALL) has a dismal outcome [2]. Patients pretreated with high-dose chemotherapy show intolerance to further alloHST, thus resulting into high transplant-related mortality and unsatisfactory overall survival. The attempts to achieve deep remission with acceptable toxicity lead to development of new immunomediated approaches, i.e., the so-called "bridge-therapy". Initial studies report comparable CR rates when applying Blinatumomab and Inotuzumab ozogamicin with a trend for blinatumomab administration in the setting of minimal residual disease, or lower marrow blast percentages without CNS involvement. Inotuzumab ozogamicin is effective regardless of blast counts, but there is no data about the role of leukemic blasts in extramedullar lesions [4]. Extramedullary relapses are more common after allogeneic stem cell transplantation, and may occur after Blinatumomab as well, and these patients have extremely poor prognosis [5].

\section{Case Description}

\section{Case 1.}

A 31-year old woman was diagnosed with B-ALL, isolated marrow involvement, in March, 2014. Genetic abnormalities were not evaluated at the regional hospital. The patient was treated according to the National ALL-2009 Protocol, and morphological remission was reached after first induction cycle. The protocol was completed in October 2016. One year later, in September $2017,200 \times 10^{6} \mathrm{WBC} / \mathrm{L}$ and $45 \times 10^{6} \mathrm{PLT} / \mathrm{L}$ of peripheral blood were found. The genetic tests revealed 46,XX,t(9;22)(q23;p22), and BCR/ABL p190. The dasatinib-containing ALL-REZ-MB-2013 protocol was then administered. Second morphologic remission was reached after the first cycle of this treatment. In January, 2018, the patient was sent to our center, and the genetic tests showed a molecular remission. HLA-typing revealed an identical sibling donor. However, allo-HSCT was delayed due to intestinal bleeding associated with dasatinib administration. Chemotherapy was interrupted for a month until allo-HSCT. Bone marrow (BM) examination has revealed $90 \%$ of blasts a month later, with CD $45 \mathrm{dim} / \mathrm{CD} 19+/ \mathrm{CD} 10+/$ CD34+/CD38+/CD22+/CD20+/CD13+/sIgM-/cytIgM-/ cytCD79a+ phenotype, CD19 expression on $99.6 \%$ of the cells; conventional cytogenetics showed 46-47,XX,?t(4;9) (q25;p24), $\operatorname{del}(6)(\mathrm{q} 23 \mathrm{q} 25), \mathrm{t}(9 ; 22)(\mathrm{q} 34 ; \mathrm{q} 22), \operatorname{add}(11)(\mathrm{p} 11)$, $\operatorname{del}(14)(\mathrm{q} 24),-18,-20$, add(21)(q22), + mar2-3 [19], mutIKAROSIKZF1. Liquor assay was normal, no extramedullar lesions were found. Blinatumomab was administered as 4-week prolonged infusion after a pre-phase of cyclophosphamide treatment $(200 \mathrm{mg} / \mathrm{kg})$. Tyrosine kinase inhibitor therapy was switched to nilotinib. The treatment was well tolerated, any non-hematologic toxicity was observed. Two weeks after Blinatumomab treatment, the patient exhibited fever, weakness, swelling of eyelids, enlargement of mandibular lymph nodes and breast. BM exam revealed $18 \%$ of blast cells, with CD19 expression (88.6\%), CD22 expression
(97.9\%). BCR-ABL p190/ABL*100 33.5534 copies, IKAROS mut. Inotuzumab ozogamicin was administered for vital indications in the frame of extended access program 3 times weekly after pre-phase of cyclophosphamide. Inotuzumab treatment was well tolerated, non-hematologic toxicity (hepatic grade 3, ALT elevation) was reversible. Complete BM and EM was achieved, MRD was detected by RT-PCR: BCR/ ABL p190 was detected at 0.0637 copies. Allogeneic stem cell transplantation from matched related donor was performed at 09.08.2018, i.e., three weeks after Inotuzumab. Conditioning regimen with reduced toxicity included Fludarabine and Busulfan (10 mg/kg). GVHD prophylaxis was performed with posttransplant cyclophosphamide. Engraftment with complete donor chimerism and MRD negativity was reached at day+24. No signs of sinusoidal occlusive syndrome were observed, and no acute GVHD occurred. Donor lymphocyte infusion CD3 $+1 \times 10^{6} / \mathrm{kg}$ was carried out at day +74 as a relapse prophylaxis. Tyrosine kinase inhibitor bosutinib was administered with adverse effects, thus later switched to imatinib. Chronic GVHD of skin and mucosa has developed 4 months after allo-HSCT. Tacrolimus was implicated at D+130 in order to control GVHD. At the present time, 11 months after HSCT, the patient is in complete MRD-negative remission with mild cGVHD controlled by tacrolimus. Imatinib treatment is continued.

\section{Case 2.}

A 25-year old young woman was diagnosed in November, 2011 with B-ALL blast cells showing CD79a+/HLADR+ CD19+/CD10+/CD38+/CD22+/CD20+/CD5-/sIgM-/cytIgM-/ phenotype, isolated BM involvement. Conventional cytogenetics showed normal karyotype. The patient received the National ALL-2009 Protocol with rituximab. Morphological remission was achieved after first induction cycle. The protocol was completed in April, 2014. BM relapse occurred in May, 2015. Blasts characteristics didn't differ from initial levels. The second remission was achieved after first cycle of HyperCVAD protocol. A search for unrelated matched donor was launched. Second BM and CNS relapse accomplished by the breast lesions was diagnosed after the $3^{\text {rd }}$ HyperCVAD cycle. Morphological remission with incomplete hematologic recovery was achieved after salvage therapy according to FLAG-Ida protocol. The chemotherapy was complicated by severe non-hematologic toxicity and sistem systemic inflammatory responce syndrome (SIRS). Allogeneic stem cell transplantation from matched unrelated donor was performed at 25.11.2015. The reduced-toxicity conditioning regimen included Fludarabine and Busulfan (12 $\mathrm{mg} / \mathrm{kg})$, GVHD prophylaxis was performed with tacrolimus, mycophenolate mofetil (MMF), and posttransplant cyclophosphamide. Stem cell engraftment with complete donor chimerism and MRD negativity was reached at day +20 . However, on the day+50, BM and liquor assays revealed $3^{\text {rd }}$ bone marrow relapse. The patient received Blinatumomab as a 4 -week continuous infusion. The cytokine release syndrome occurred on day 2 , being successfully treated with Tocilizumab, an anti-IL-6 receptor antagonist. The patient achieved $4^{\text {th }}$ remission with complete donor chimerism. However, MRD was detected by flow cytometry. Next two cycles of Blinatumomab were applied with a dose reduction followed by donor lymphocyte infusion (DLI). No signifi- 
cant toxicity was observed, and no GVHD has developed. MRD negativity was reached after $2^{\text {nd }}$ cycle. One year after transplantation patient developed an isolated left ocular extramedullary relapse. A remission was achieved after highdose methotrexate and cytarabine followed by local radiotherapy. 1.5 years later, an isolated nasal extramedullary relapse was successfully treated in similar way. Six months later, a $7^{\text {th }}$ isolated breast relapse was confirmed by the biopsy. $\mathrm{BM}$ and liquor assays revealed MRD-negative remission and complete donor chimerism. Immunohistochemistry showed CD22 positivity, thus allowing us to use Inotuzumab in the frame of extended access program for vital indications. The patients received four cycles of Inotuzumab in the outpatient regimen. Complete metabolic response was documented by PET-CT (Fig. 1).

\section{Discussion}

Extramedullary lesions are often revealed in cases of ALL relapse. Incidence of extramedullary relapses after allo-HSCT is higher than those in BM. So far, best results were demonstrated after high-dose chemotherapy followed by local radiotherapy [6]. Clinical prognosis in these patients remains very poor despite of different treatment options.

Blinotumomab is highly effective in R/R ALL patients with $69 \%$ of complete remission or complete remission with incomplete hematologic recovery achieved even after alloHSCT [7-9]. In TOWER study the 1-year, the overall survival (OS) rate was 36\% (median OS, 7.7 months), and the duration of remission was 7.3 months. Several studies including limited number of patients demonstrate similar results in Philadelphia chromosome-positive R/R ALL - up to $36 \%$ CR/CRi with median OS of 7.1 months [10]. The outcomes of Blinotumomab treatment in the patients relapsing after allo-HSCT were comparable: $45 \%$ CR/CRi and the median OS value was 8.5 months.

The Inotuzumab ozogamicin INO-VATE study included wider range of patients, e.g. Philadelphia chromosome positive R/R ALL, and the CR/CRi rate was $73.8 \%$ [4]. For patients achieving $\mathrm{CR} / \mathrm{CRi}$, the duration of remission was 5.2 months with 3-year OS rates of $20.3 \%$ (median 7.7 months). $\mathrm{CR} / \mathrm{CRi}$ rate in patients who received previous allo-HSCT was similar, i.e., $69 \%$.

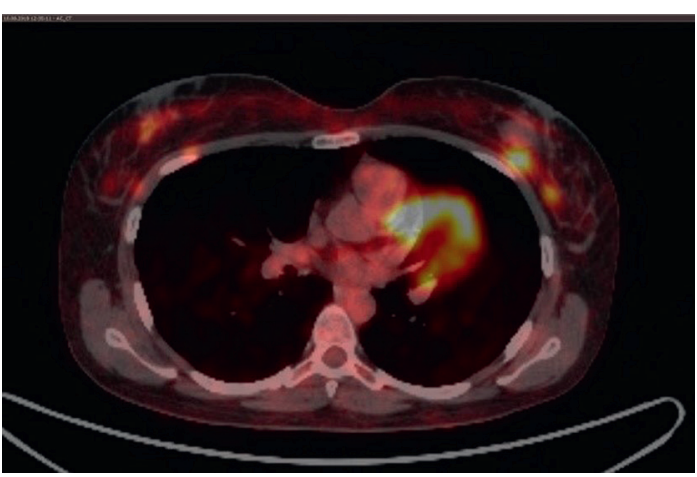

Despite versatile analysis of these innovative drugs, no study has assessed their efficacy in the cases of extramedullary lesions. Some data about Blinotumomab and Inotuzumab ozogamicin impact on soft tissue tumors in limited studies are obtained in relapsed or refractory B-cell non-Hodgkin lymphoma. Viardot et al. report $43 \%$ overall response, including $19 \%$ of complete remissions after Blinotumomab treatment[11]. The results of Phase I study from Goebeler et al. showed $55 \%$ of overall response with complete remission in $36 \%$ of the cases [12].

Inotuzumab ozogamicin demonstrates better results only in combination with rituximab and chemotherapy: the overall response rate of $84 \%$ was reported, with CR values of $24 \%$, but only $57 \%$ overall response in the patients with histologically aggressive lymphoma [13]. These results from NHL trials are not encouraging, with respect to high efficacy of Blinotumomab and Inotuzumab ozogamicin in R/R ALL with extramedullar involvement.

\section{Conclusion}

Inotuzumab ozogamicin is feasible and effective for highly pre-treated patients with R/R ALL before and after alloHSCT. Despite moderate efficacy of immunotherapy in treatment of extramedullar R/R ALL, it may be further enhanced with additional immune strategies such as anti-PD-1 immunotherapy agents.

\section{Conflict of Interest}

No conflict of interest is declared.

\section{References}

1. Giebel S, Marks DI, Boissel N, Baron F, Chiaretti S, Ciceri F, Cornelissen JJ, Doubek M, Esteve J, Fielding A et al. Hematopoietic stem cell transplantation for adults with Philadelphia chromosome-negative acute lymphoblastic leukemia in first remission: a position statement of the European Working Group for Adult Acute Lymphoblastic Leukemia (EWALL) and the Acute Leukemia Working Party of the European Society for Blood and Marrow Transplantation (EBMT). Bone Marrow Transplant. 2019; 54(6):798-809.

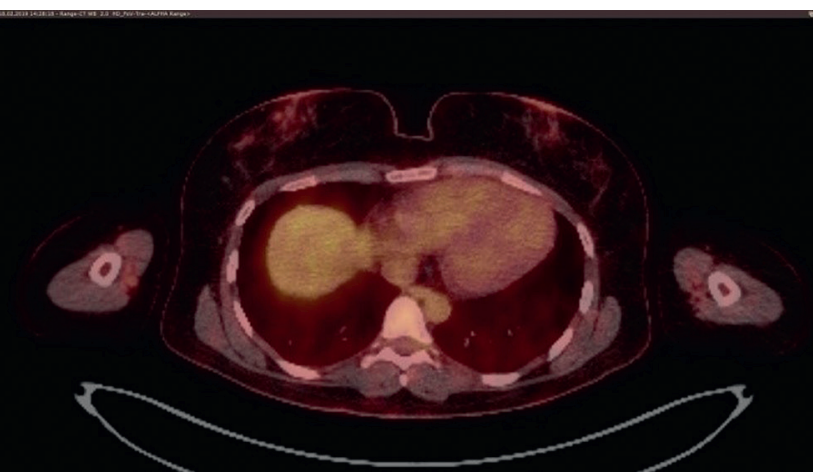

Figure 1. PET-CT scan before Inotuzumab treatment, SULmax 11.93 (A) and after the forth cycle of Inotuzumab (B) 
2. Gökbuget N, Dombret H, Ribera JM, Fielding AK, Advani A, Bassan R, Chia V, Doubek M, Giebel S, Hoelzer D et al. International reference analysis of outcomes in adults with B-precursor Ph-negative relapsed/refractory acute lymphoblastic leukemia. Haematologica. 2016;101(12):1524-1533.

3. Rafei H, Kantarjian HM, Jabbour EJ. Recent advances in the treatment of acute lymphoblastic leukemia. Leuk Lymphoma. 2019; 16:1-16.

4. Kantarjian HM, De Angelo DJ, Stelljes M, Liedtke M, Stock W, Gökbuget N, O'Brien SM, Jabbour E, Wang T, Liang White $\mathrm{J}$ et al. Inotuzumab ozogamicin versus standard of care in relapsed or refractory acute lymphoblastic leukemia: Final report and long-term survival follow-up from the randomized, phase 3 INO-VATEstudy. Cancer. 2019;125(14): 2474-2487.

5. Gunes G, Goker H, Demiroglu H, Malkan UY, Buyukasik Y. Extramedullary relapses of acute leukemias after allogeneic hematopoietic stem cell transplantation: clinical features, cumulative incidence, and risk factors. Bone Marrow Transplant. 2019; 54(4):595-600.

6. Shi JM, Meng XJ, Luo Y, Tan YM, Zhu XL, Zheng GF, He JS, Zheng WY, Xie WZ, Li L et al. Clinical characteristics and outcome of isolated extramedullary relapse in acute leukemia after allogeneic stem cell transplantation: a single-center analysis. Leuk Res. 2013; 37(4):372-377.

7. Kantarjian H, Stein A, Gökbuget $\mathrm{N}$ et al. Blinatumomab versus Chemotherapy for Advanced Acute Lymphoblastic Leukemia. N Engl J Med. 2017; 376(9): 836-847.

8. Stein AS, Kantarjian H, Gökbuget N, Fielding AK, Schuh AC, Ribera JM, Wei A, Dombret H, Foà R, Bassan R et al. Blinatumomab for acute lymphoblastic leukemia relapse after allogeneic hematopoietic stem cell transplantation. Biol Blood Marrow Transplant. 2019 Apr 17.

9. Bondarenko SN, Parovichnikova EN, Maschan AA, Baranova OYu, Shelekhovas TV, Doronin VA, Mel'nichenko VYa, Kaplanov KD, Uspenskaya OS, Sokolov AN et al. Blinatumomab in the Treatment of Acute Lymphoblastic Leukemia: Russian Multicenter Clinical Trial. Clinical Oncohematology. 2019;12(2):145-153 (In Russ).

10. Martinelli G, Boissel N, Chevallier P, Ottmann O, Gökbuget N, Topp MS, Fielding AK, Rambaldi A, Ritchie EK, Papayannidis C et al. Complete Hematologic and Molecular Response in Adult Patients With Relapsed/Refractory Philadelphia Chromosome-Positive B-Precursor Acute Lymphoblastic Leukemia Following Treatment With Blinatumomab: Results From a Phase II, Single-Arm, Multicenter Study. J Clin Oncol. 2017;35(16):1795-1802.

11. Viardot A, Goebeler ME, Hess G, Neumann S, Pfreundschuh M, Adrian N, Zettl F, Libicher M, Sayehli C, Stieglmaier J et al. Phase 2 study of the bispecific T-cell engager (BiTE) antibody blinatumomab in relapsed/refractory diffuse large B-cell lymphoma. Blood. 2016;127(11):1410-1416.

12. Goebeler ME, Knop S, Viardot A, Kufer P, Topp MS, Einsele H, Noppeney R, Hess G, Kallert S, Mackensen A et al. Bispecific T-Cell Engager (BiTE) Antibody Construct Blinatumomab for the Treatment of Patients With Relapsed/
Refractory Non-Hodgkin Lymphoma: Final Results From a Phase I Study. J Clin Oncol. 2016; 34(10):1104-1111.

13. Dang NH, Ogura M, Castaigne S, Fayad LE, Jerkeman M, Radford J, Pezzutto A, Bondarenko I, Stewart DA, Shnaidman $\mathrm{M}$ et al. Randomized, phase 3 trial of inotuzumab ozogamicin plus rituximab versus chemotherapy plus rituximab for relapsed/refractory aggressive B-cell non-Hodgkin lymphoma. Br J Haematol. 2018; 182(4):583-586. 


\title{
Успешная терапия резистентного В-острого лимфо- бластного лейкоза с экстрамедуллярным поражени- ем с применением инотузумаба озогамицина до и после аллогенной трансплантации гемопоэтических стволовых клеток
}

\author{
Анна Г. Смирнова, Сергей Н. Бондаренко, Иван С. Моисеев, Инна В. Маркова, Елена И. Дарская, \\ Ирина К. Голубовская, Белла И. Аюбова, Елена В. Бабенко, Ильдар М. Бархатов, Александр Л. Алянский, \\ Татьяна Л. Гиндина, Александр Д. Кулагин, Борис В. Афанасьев \\ НИИ детской онкологии, гематологии и трансплантологии им. Р. М. Горбачевой, Первый Санкт-Петербургский \\ государственный медицинский университет им. акад. И. П. Павлова, Санкт-Петербург, Россия
}

\section{Резюме}

Последние достижения в терапии резистентного В-острого лимфобластного лейкоза связаны с иммуноопосредованными методами, такими как Блинатумомаб, Инотузумаб Озогамицин и CAR-T клетки. Несколько клинических исследований демонстрируют более высокую частоту полных ремиссии и реализаций алло-ТГСК после терапии Блинатумомабом и Инотузумабом по сравнению со стандартной химиотерапией при разном профиле токсичности. Но проблема лечения пациентов с наличием экстрамедуллярных поражений не отражена в этих исследованиях.

\section{Клинические описания}

В статье описаны два случая резистентного В-ОЛЛ с экстрамедуллярным поражением. Случай 1 . Женщина 31 года, диагноз $\mathrm{B}-\mathrm{OЛЛ,} \mathrm{Ph}$-позитивный, второй рецидив, нет ответа после терапии Блинотумомабом. Прогрессия с вовлечением костного мозга, шейных и нижнечелюстных лимфатических узлов и молочной железы, полная ремиссия была достигнута после проведения терапии Инотузумабом.
Впоследствии выполнена аллогенная родственная трансплантация гемопоэтических стволовых клеток. Случай 2. Женщина 25 лет, ранний изолированный костно-мозговой рецидив после аллогенной неродственной трансплантации. После терапии Блинотумомабом была достигнута ремиссия. Инотузумаб назначен при развитии 6-ого экстрамедуллярного рецидива. Полный метаболический ответ был достигнут после 4 курсов терапии Инотузумабом.

\section{Заключение}

Описанные случаи демонстрируют возможность применения Инотузумаба при неэффективности Блинотумомаба в случае развития экстрамедуллярного рецидива до и после аллогенной трансплантации гемопоэтических стволовых клеток.

\section{Ключевые слова}

Аллогенная трансплантация гемопоэтических стволовых клеток, В-острый лимфобластный лейкоз, Блинотумомаб, Инотузумаб озогамицин, экстрамедуллярный рецидив. 